\title{
Sistem Deteksi Bola pada Robot Kiper Pemain Sepak Bola Beroda
}

\author{
Rifqi Amalya Fatekha ${ }^{1,2}$, Bima Sena Bayu Dewantara ${ }^{2}$, Hary Oktavianto ${ }^{2}$ \\ ${ }^{1}$ Politeknik Negeri Batam \\ ${ }^{2}$ Politeknik Elektronika Negeri Surabaya \\ e-mail : rifqi@polibatam.ac.id, bima@pens.ac.id, hary@pens.ac.id
}

\begin{abstract}
Abstrak
Perkembangan pada dunia robotika pada saat ini semakin pesat, di mana robot dapat berguna dalam setiap kegiatan manusia. Di Indonesia ajang kontes robot sudah dilakukan pada setiap tahunnya baik tingkat regional dan tingkat nasional. Salah satu kategori yang ingin dibahas dalam penelitian ini adalah kategori Kontes Robot Sepak Bola Indonesia (KRSBI). Pada kategori ini, robot harus bisa bernavigasi untuk mencari bola dan menendang ke arah gawang. Tujuan utama dari robot ini adalah bernavigasi dan mencari bola sampai ke arah gawang lawan. Robot sepak bola beroda merupakan salah satu kategori robot yang pertama kali dipertandingkan pada KRI (Kontes Robot Indonesia) 2018 kategori KRSBI divisi beroda. Robot sepak bola dikembangkan agar memiliki fungsi yang mirip dengan pemain sepak bola pada umumnya yaitu mengejar bola, menggiring bola, dan menendang bola. Salah satu permasalahan yang masih dikembangkan sampai saat ini adalah bagaimana robot mampu mendeteksi bola menggunakan sensor kamera (webcam). Deteksi bola merupakan salah satu langkah awal dalam menentukan aksi selanjutnya robot sepak bola beroda seperti mengejar, menggiring, dan menendang bola. Karena bola yang digunakan pada pertandingan berwarna oranye maka pada penelitian ini dikembangkan pendeteksian bola menggunakan metode filter warna. Robot penjaga gawang bertugas untuk dapat menghadang bola berwarna oranye memasuki gawang. Robot tersebut harus mampu mendeteksi bola dengan akurat untuk menentukan pergerakan robot selanjutnya. Artikel ini mendeskripsikan pengembangan robot penjaga gawang yang mampu mendeteksi warna dan bentuk bola dengan metode HoughCircle dan approxPolyDP.
\end{abstract}

Kata kunci: Robotika, Robot Kiper, Robot Kiper Sepak Bola Beroda, KRSBI

\begin{abstract}
Developments in the world of robotics are currently growing where robots can be useful in every human activity, the role of robots at this time is already able to help in human work. In Indonesia, the robot contest has been held every year, both at the regional and national levels. One of the categories to be discussed in this research is the Kontes Robot Sepak Bola Indonesia (KRSBI) category. In this category, the robot must be able to navigate to find the ball and kick towards the goal. The main goal of this robot is to navigate and find the ball towards the opponent's goal. Wheeled soccer robot is one of the robot categories that was first competed in 2018 at the KRI (Kontes Robot Indonesia) KRSBI wheeled division category. The soccer robot was developed to have functions similar to football players in general, namely chasing the ball, dribbling, and kicking the ball. One of the problems that are still being developed today is how the robot is able to detect the ball using a camera sensor (webcam). Ball detection is one of the first steps in determining the next action of the wheeled soccer robot such as chasing, dribbling, and kicking the ball. Because the ball used in the match is orange, this study developed ball detection using the color filter method. The goalkeeping robot is tasked with being able to block the orange ball from entering the goal. The robot must be able to detect the ball accurately to determine the next robot's movement. This article describes the development of a goalkeeper robot that is able to detect the color and shape of the ball using the HoughCircle and approxPolyDP methods.
\end{abstract}

Keyword: Robotics, Goalkeeper Robot, Wheeled Soccer Goalkeeper Robot, KRSBI

\section{Pendahuluan}

Teknologi saat ini sedang berkembang sejalan dengan kebutuhan manusia yang kompleks sehingga membutuhkan sebuah teknologi robotika. Robot dikembangkan sehingga memiliki kemampuankemampuan khusus yang dapat berpikir dan bersikap seperti manusia [1]. Robot memiliki peranan penting 
bagi manusia diberbagai bidang seperti kesehatan, pertanian, maupun teknologi manufaktur. Dengan perkembangan teknologi robotika, banyak pekerjaan manusia sudah terbantu oleh robot [2]. Robot diciptakan untuk membantu manusia dalam kehidupan sehari-hari mulai dari sesuatu yang ringan hingga berat [3]. Salah satu jenis robot yang banyak dikembangkan oleh peneliti yaitu robot sepak bola. Robot sepak bola adalah salah satu bidang robotik yang terus berkembang sebagai representasi kemajuan teknologi [4]. Hal tersebut didukung dengan adanya kegiatan Kontes Robot Indonesia (KRI) kategori Kontes Robot Sepak Bola Indonesia (KRSBI) setiap tahunnya di Indonesia untuk menampung dan meningkatkan minat, bakat, dan kemampuan peneliti [5]. Kontes Robot Sepak Bola Indonesia (KRSBI) diadakan setiap tahun oleh Kementerian Riset, Teknologi, dan Pendidikan Tinggi Republik Indonesia (KEMENRISTEKDIKTI) mulai tahun 2017 [6]. Kontes Robot Sepak Bola Indonesia Beroda diselenggarakan menyesuaikan kondisi di Indonesia, misalnya untuk ukuran lapangan dan lain sebagainya [7].

Secara umum, robot sepak bola dibagi menjadi dua kategori, yaitu humanoid dan beroda. Robot humanoid adalah robot yang memiliki bentuk seperti manusia dengan dua tangan, dua kaki, batang tubuh, dan kepala [8]. Namun, robot humanoid memiliki kekurangan di antaranya adalah kebebasan gerak, keseimbangan, dan biaya pembuatan. Oleh karena itu, robot sepak bola beroda merupakan solusi dari permasalahan penggunaan robot humanoid karena memiliki tingkat kesulitan yang lebih rendah dalam mengatur keseimbangan robot dalam melakukan misi [9].

Robot sepak bola memiliki misi, yaitu mencari bola [10], mencari gawang, menggiring bola, dan menghindari halangan [11]. Semua misi dapat dijalankan dengan menggunakan kontrol otomatis berbasis artificial intelligence (AI) yang dapat melakukan tugas sesuai dengan instruksi yang diberikan [12]. Untuk menjalankan tugas mencari bola, gawang dan menggiring bola membutuhkan metode tracking object [13]. Layaknya seorang pemain sepak bola profesional, maka platform robot ini membutuhkan suatu mekanisme penendang bola sehingga robot dapat mencetak gol ke gawang lawan [14]. Salah satu peneliti menggunakan metode thresholding pada warna bola dan gawang secara bergantian.

Namun pada robot sepak bola beroda [15], robot harus bisa memainkan bola di lapangan sama seperti pemain sepak bola [5]. Secara umum, robot memiliki keterbatasan dalam pergerakannya [15], dimana robot tidak dapat bergerak kesuatu posisi secara akurat. Keterbatasan dalam pergerakan ini meliputi pergerakan robot untuk bisa bergerak ke kiri, kanan, dan diagonal tanpa mengubah orientasi [16]. Hal ini menyebabkan robot tidak dapat memainkan bola dengan baik sehingga misi yang diberikan tidak dapat diselesaikan dengan baik [17].

Beberapa metode yang digunakan untuk pendeteksian bola sebagai objek yang dideteksi telah dilakukan sebelumnya, yaitu penggunaan Local Binary Pattern (LBP) [4], PeleeNet [6], dan Neural Network [15] yang mana masih membutuhkan perangkat keras yang mumpuni agar dapat mencapai performa yang diinginkan. Pada penelitian ini digunakan metode HoughCircle dan approxPolyDP [5] untuk mendeteksi bola, yang menjadi sebuah solusi yang dapat digunakan pada perangkat keras yang tidak memerlukan spesifikasi yang tinggi.

\section{Metode Penelitian}

Objek penelitian ini adalah robot kiper yang dikonteskan pada KRSBBI (Kontes Robot Sepak Bola Beroda Indonesia). Robot kiper berfungsi menghadang bola yang akan masuk kedalam gawang yang dijaganya. Dalam melakukan tugasnya tersebut, kiper memerlukan sebuah sistem yang dapat membantunya. Salah satu sistem utamanya adalah sistem deteksi bola. Sistem deteksi bola ini menggunakan sensor vision (kamera). Data yang diolah adalah data streaming dari kamera yang diproses frame by frame.

\subsection{Desain Sistem}

Pada bagian ini dijelaskan sistem robot secara keseluruhan. Gambar 1 menunjukkan blok diagram dari sistem robot sepak bola beroda.

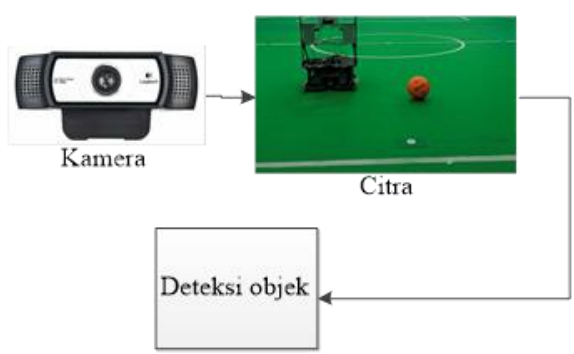

Gambar 1. Blok Diagram Sistem

Sistem yang dibangun menggunakan kamera Logitech seri c930e yang memiliki kemampuan menangkap gambar $30 \mathrm{fps}$ sebagai sensor yang menghasilkan data masukan dan menggunakan komputer mini Intel NUC dengan prosesor i3, RAM sebesar 4GB dan SSD 128 GB. Sedangkan perangkat lunak dibangun didalam Robot Operating System (ROS) dan menggunakan bahasa pemrograman $\mathrm{C}++$.

\subsection{Pendeteksian Bola}

Pendeteksian bola pada robot sepak bola beroda ini menggunakan sebuah program yang akan mengolah setiap frame gambar dari kamera, yang kemudian diproses untuk mendapatkan informasi tentang objek seperti robot dan bola. Didalam sistem 
deteksi objek, ada beberapa proses seperti yang ditunjukkan pada Gambar 2.

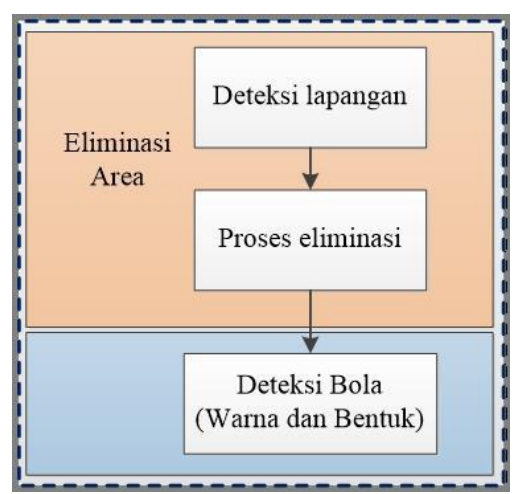

Gambar 2. Proses Pendeteksian Bola

Proses pendeteksian bola memanfaatkan 2 fitur utama, yaitu warna dan bentuk. Warna bola adalah oranye (sesuai aturan KRSBBI) dan berbentuk bulat/lingkaran. Pergerakan bola dibatasi hanya bola yang bergerak menyusuri lapangan saja.

Proses deteksi objek dimulai dari proses eliminasi. Proses ini dimaksudkan untuk membedakan posisi bola ada didalam atau diluar lapangan. Contoh gambar yang diproses ditunjukkan pada Gambar 3.

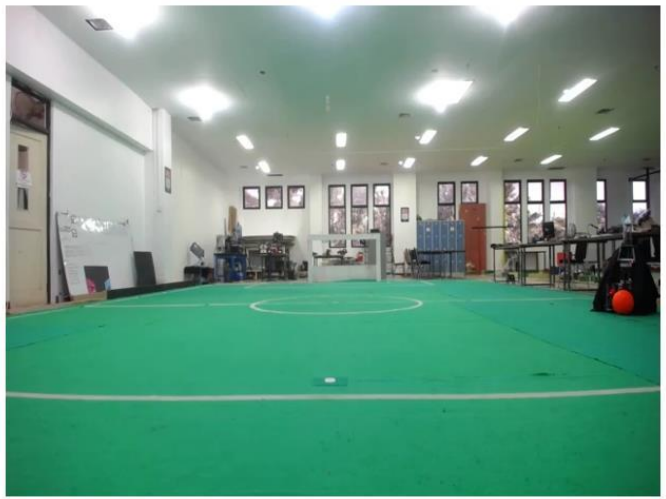

Gambar 3. Contoh Citra Masukan

Untuk proses eliminasi sendiri, lebih menggunakan proses thresholding warna. Warna yang digunakan adalah warna dominan lapangan, yaitu warna hijau. Dari hasil seleksi warna ini kemudian dikombinasikan dengan beberapa proses morfologi dan binari hingga didapatkan hasil proses eliminasi sesuai dengan yang diinginkan. Blok diagram proses eliminasi dapat dilihat pada Gambar 4.

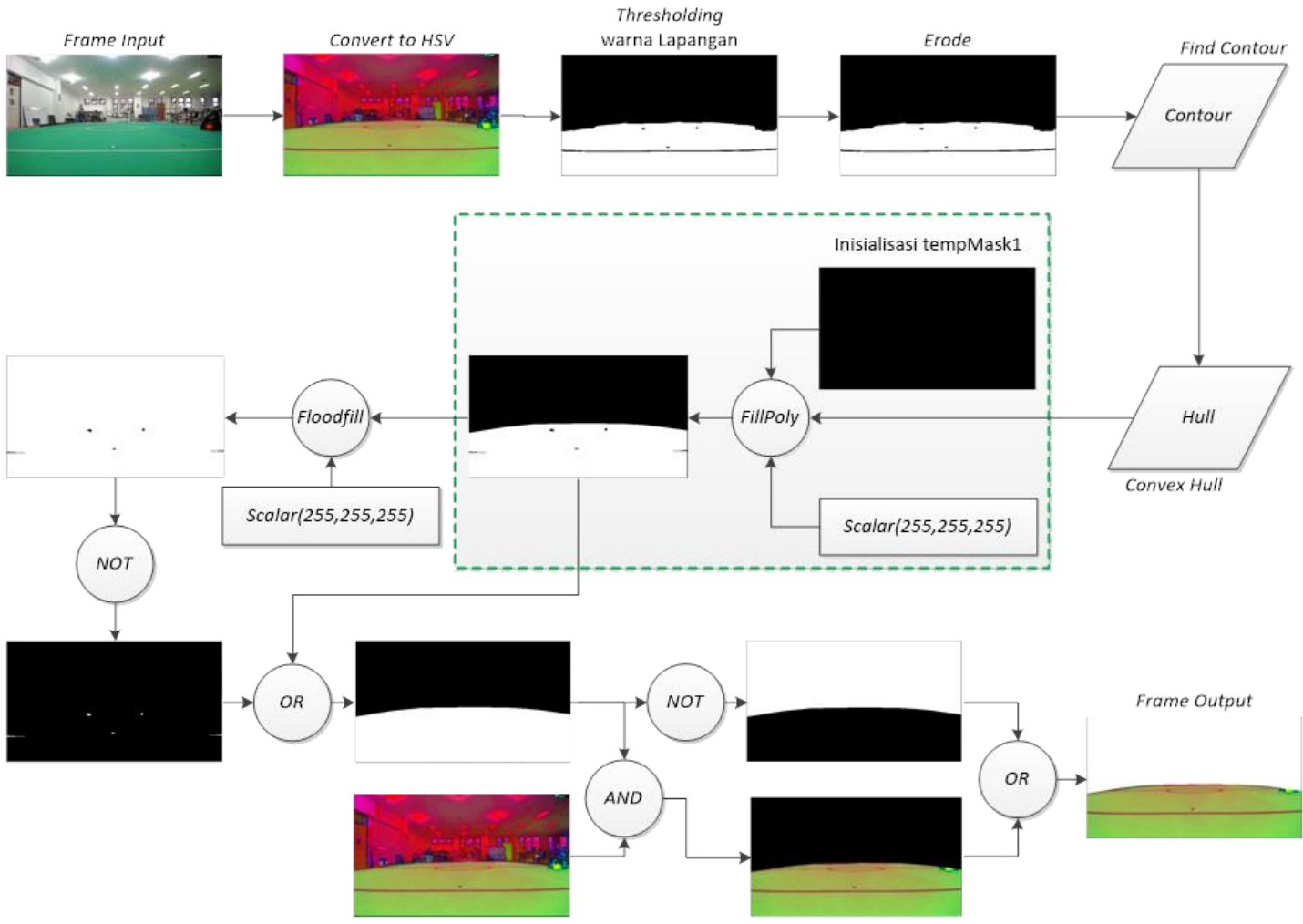

Gambar 4. Blok Diagram Proses Eliminasi

3. Hasil dan Pembahasan
Dari Gambar 4, Hasil dari proses deteksi lapangan yang ditunjukkan pada Gambar 5 akan 
dijadikan sebagai citra masukan. Proses selanjutnya yaitu deteksi contour yang kemudian semua contour akan dihubungkan menjadi satu area dengan fungsi convexHull dan fillPoly. Untuk mulai mengeliminasi area luar lapangan pada citra, diawali dengan mengisi keseluruhan citra yang diproses dengan warna putih menggunakan floodFill. Hasil dari proses floodFill kemudian dibalik nilainya menggunakan operasi binari NOT, sehingga menghasilkan citra yang dominan berwarna hitam. Citra ini nantinya akan dikombinasikan dengan citra hasil proses fillPoly yang masih menyisakan area hitam walaupun berada di dalam lapangan. Area hitam ini dapat ditimbulkan karena ada objek yang tidak memiliki warna yang sama dengan lapangan, seperti garis putih, bola, atau bahkan robot.

Pengkombinasian citra ini menggunakan operasi binari $O R$. Proses tersebut akan menandai semua area lapangan dengan warna putih. Citra ini akan digabungkan dengan citra masukan yang sudah dalam format HSV menggunakan operasi binari $A N D$. Hasilnya berupa citra yang hanya menampilkan area lapangan secara utuh beserta objek yang ada di dalamnya, sedangkan area luar lapangan akan berwarna hitam. Proses tidak berhenti sampai di sini, warna hitam pada citra harus dirubah menjadi warna selain warna hitam dan oranye. Hal ini dikarenakan nantinya akan menimbulkan masalah saat akan mendeteksi objek yang diinginkan, karena warna objek yang ingin dideteksi dominannya adalah hitam untuk robot dan oranye untuk bola. Hasil operasi binari $O R$ akan diduplikasi dan dibalik nilainya menggunakan operasi binari NOT, kemudian digabungkan kembali dengan hasil citra yang area luar lapangannya telah berwarna hitam menggunakan operasi binari $O R$. Area luar lapangan yang tadinya berwarna hitam akan berubah menjadi berwarna putih seperti pada Gambar 6, citra keluaran dari proses ini siap untuk digunakan pada proses deteksi objek.

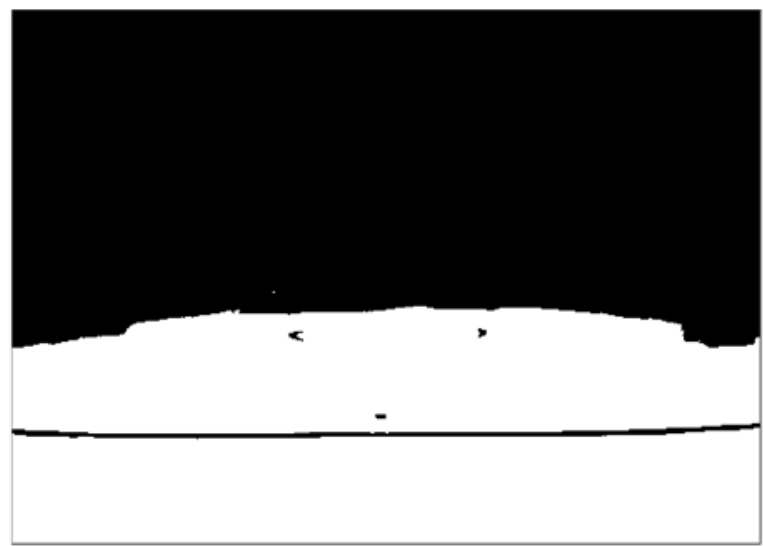

Gambar 5. Citra Masukan Proses Eliminasi

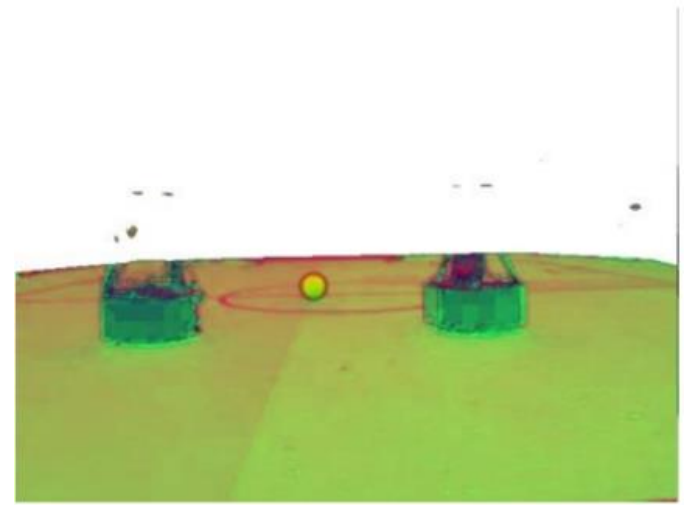

Gambar 6. Hasil Proses Eliminasi

Proses selanjutnya yang dilakukan peneliti adalah mendeteksi bola berdasarkan pada warna (oranye) dan bentuknya (lingkaran). Langkah yang dilakukan ditunjukkan pada Gambar 7.
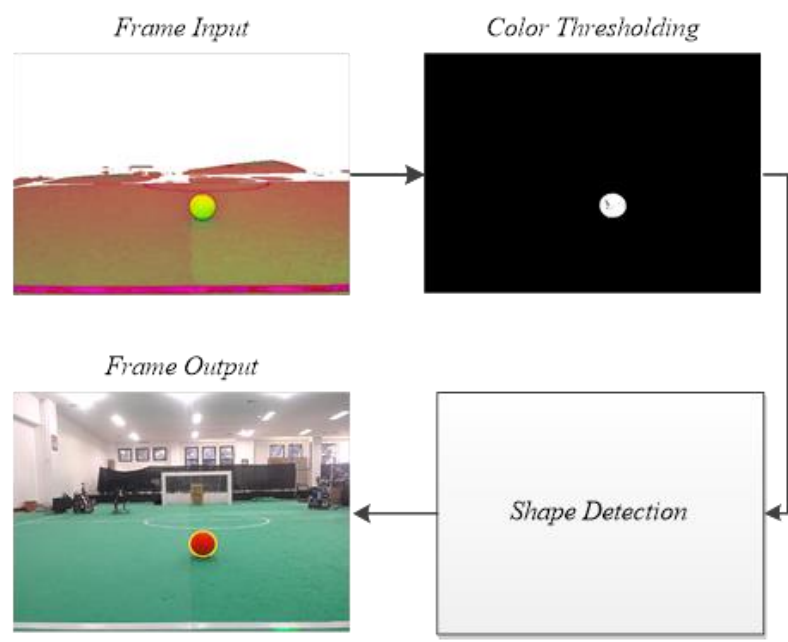

Gambar 7. Deteksi Bola Berdasarkan Warna dan Bentuk

Frame input didapat dari hasil proses eliminasi sebelumnya. Kemudian dilakukan penyeleksian warna (color thresholding) menggunakan fungsi inRange dari library openCV sesuai warna bola dengan memanfaatkan ruang warna HSV nilai warna bola pada ruang HSV telah ditentukan sebelumnya.

Setelah itu, hasil seleksi warna akan dilanjutkan dengan proses deteksi bentuk, untuk melihat bentuknya lingkaran atau bukan. Untuk proses deteksi bentuk, ada dua cara yang telah dilakukan, yaitu dengan metode HoughCircle dan menggunakan fungsi approxPolyDP.

Deteksi bentuk dengan metode HoughCircle dilakukan dalam beberapa tahap, seperti pada Gambar 8. Tahap awal yang dilakukan adalah melakukan operasi morfologi opening dan closing terhadap citra hasil proses color thresholding. Tahap selanjutnya adalah mendeteksi tepian area objek pada citra yang kemudian dilanjutkan kembali dengan menerapkan fungsi HoughCircle untuk menemukan bentuk lingkaran pada citra yang 
diproses. Objek-objek lingkaran yang terdeteksi kemudian akan diseleksi kembali berdasarkan kecocokan terhadap titik-titik area pada citra masukan. Objek lingkaran yang memiliki tingkat kecocokan tertinggi akan diambil sebagai data keluaran.

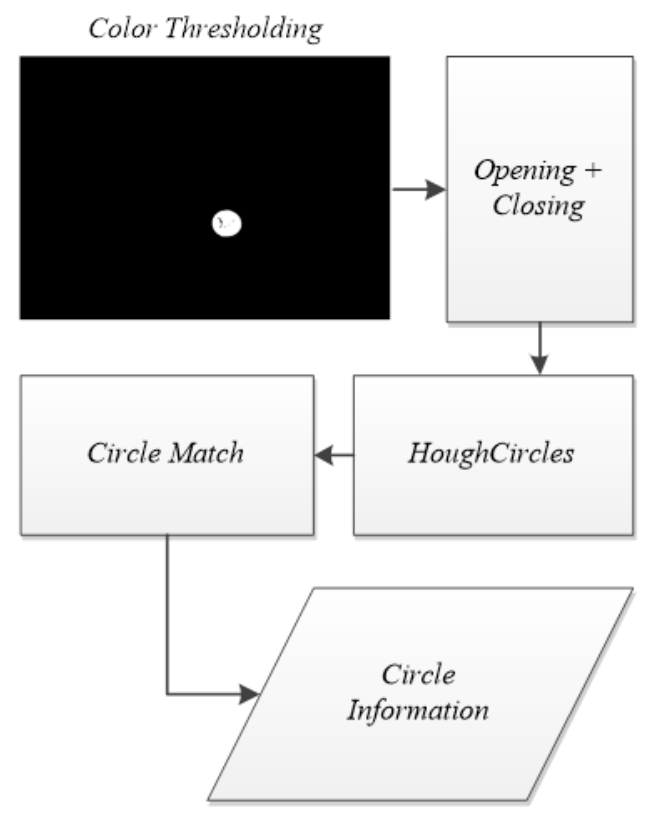

\section{Gambar 8. Deteksi Bentuk Dengan HoughCircle}

Deteksi bentuk dengan menggunakan metode approxPolyDP adalah metode yang menggunakan fungsi yang telah tersedia pada library OpenCV. Fungsi ini akan mencoba membuat garis pada objek yang ingin diproses. Jumlah garis yang terbentuk dipengaruhi oleh parameter masukan fungsi. Dari jumlah garis yang terbentuk ini nantinya dapat digunakan untuk membedakan mana objek yang memiliki bentuk lingkaran dan yang bukan lingkaran. Tahapan pada proses ini ditunjukkan pada Gambar 9. Deteksi bentuk diawali dengan proses penggabungan contour yang terdeteksi. Proses dilanjutkan dengan

deteksi ulang contour yang telah di rekonstruksi.
Hasil deteksi contour ini kemudian diproses kembali dengan menjalankan fungsi approxPolyDP untuk melihat jumlah garis yang dapat dibentuk dari contour yang ada. Karena akan ada kemungkinan terdeteksi banyak contour, dan bentuk yang diinginkan adalah lingkaran, maka ada penyeleksian data berupa data contour mana yang akan diambil. Secara ideal, semakin banyak garis yang dapat dibentuk dari sebuah contour, maka contour tersebut memiliki bentuk menyerupai lingkaran. Hasil dari proses seleksi contour ini diproses kembali hingga mendapatkan informasi yang diinginkan.

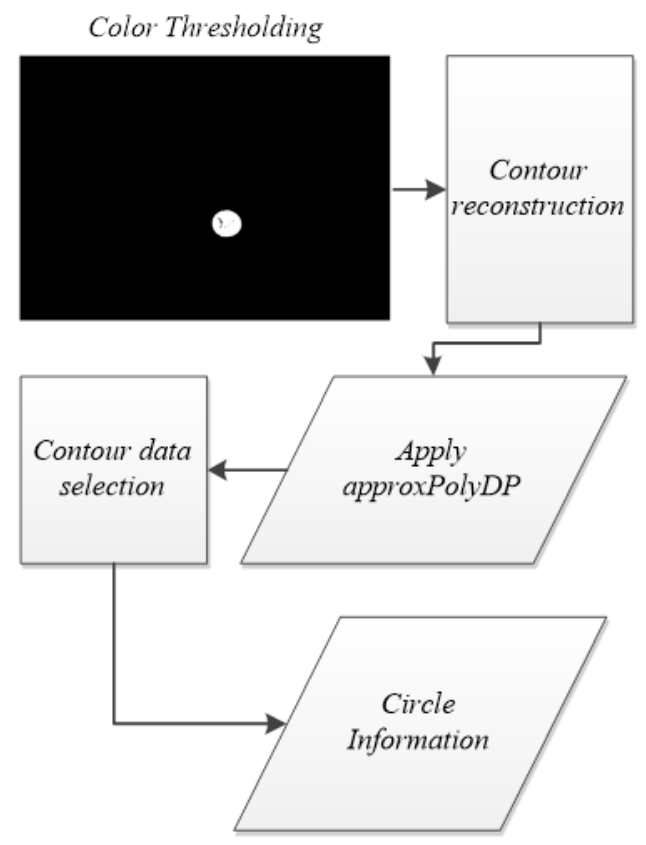

\section{Gambar 9. Deteksi Bola Dengan approxPolyDP}

Hasil dari proses deteksi bentuk berupa data lingkaran yang terdiri dari titik pusat lingkaran pada citra masukan dan radius lingkaran dalam satuan piksel. Informasi titik pusat dan radius ini kemudian ditampilkan pada citra dengan bentuk lingkaran berwarna kuning.

Tabel 1. Hasil Deteksi Bola (Warna dan Bentuk)

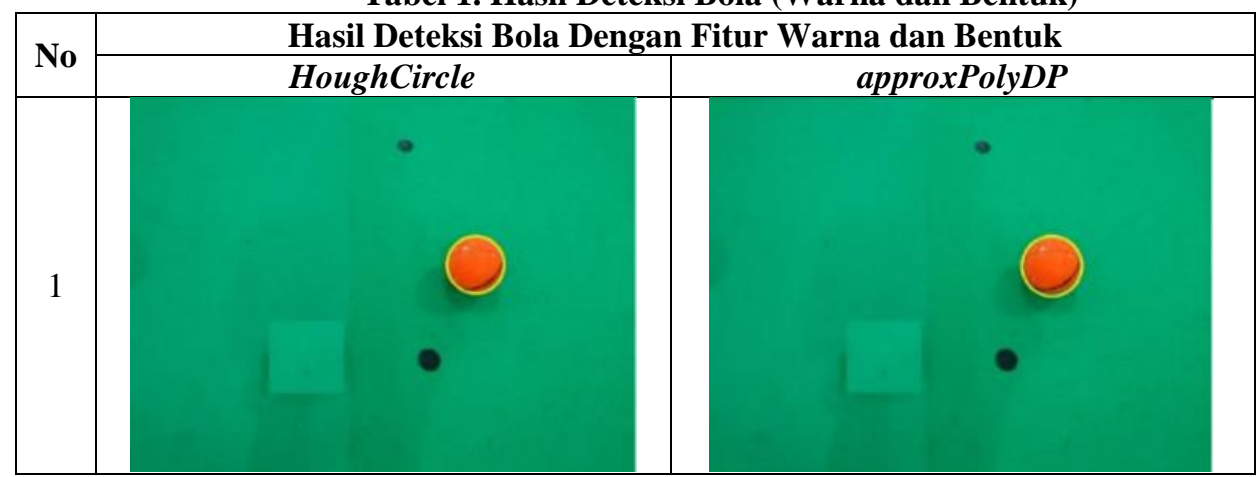




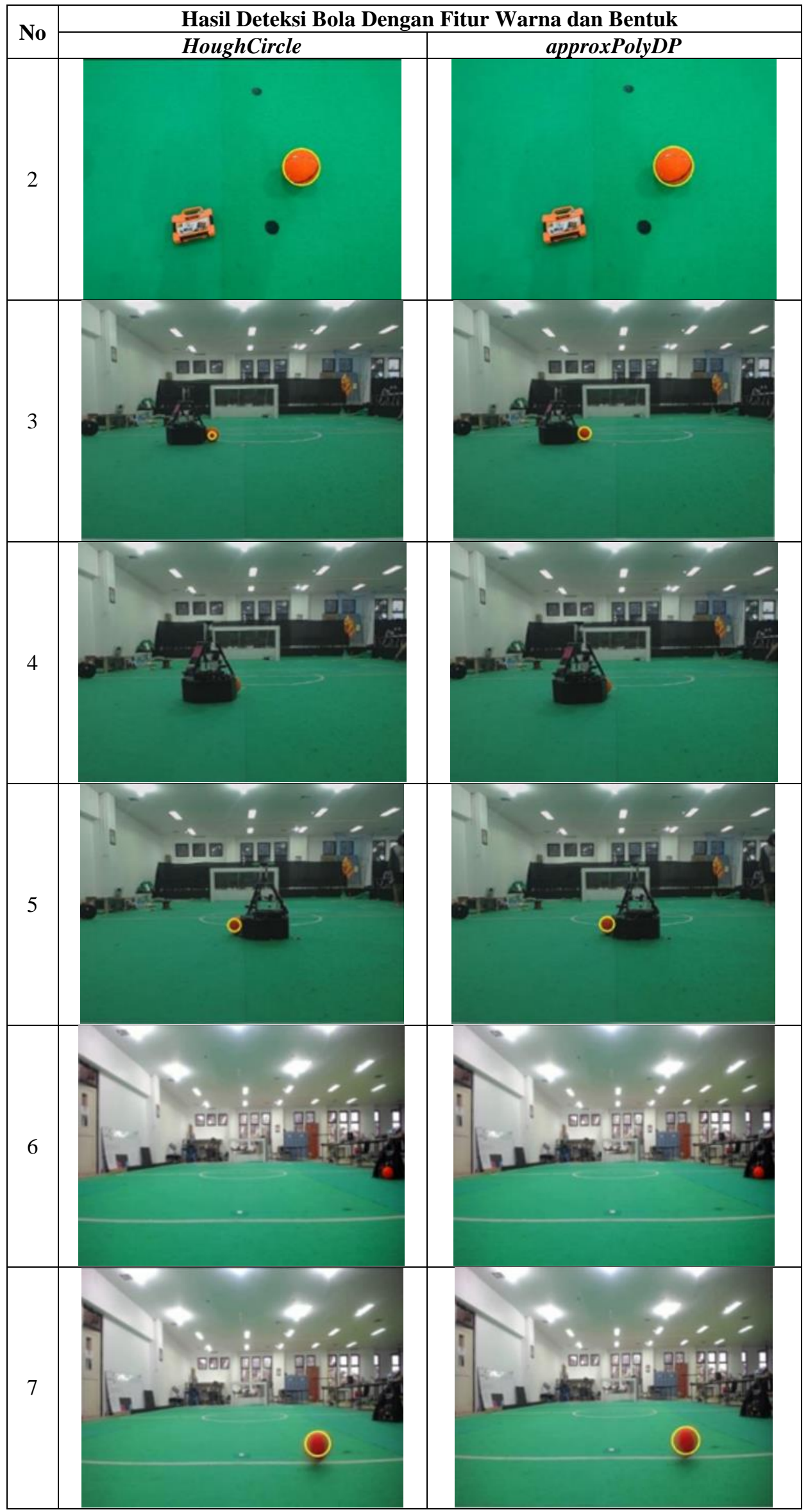

132 | Jurnal Integrasi | Vol.13 No.2, October 2021, 127-134 | e-ISSN: 2548-9828 


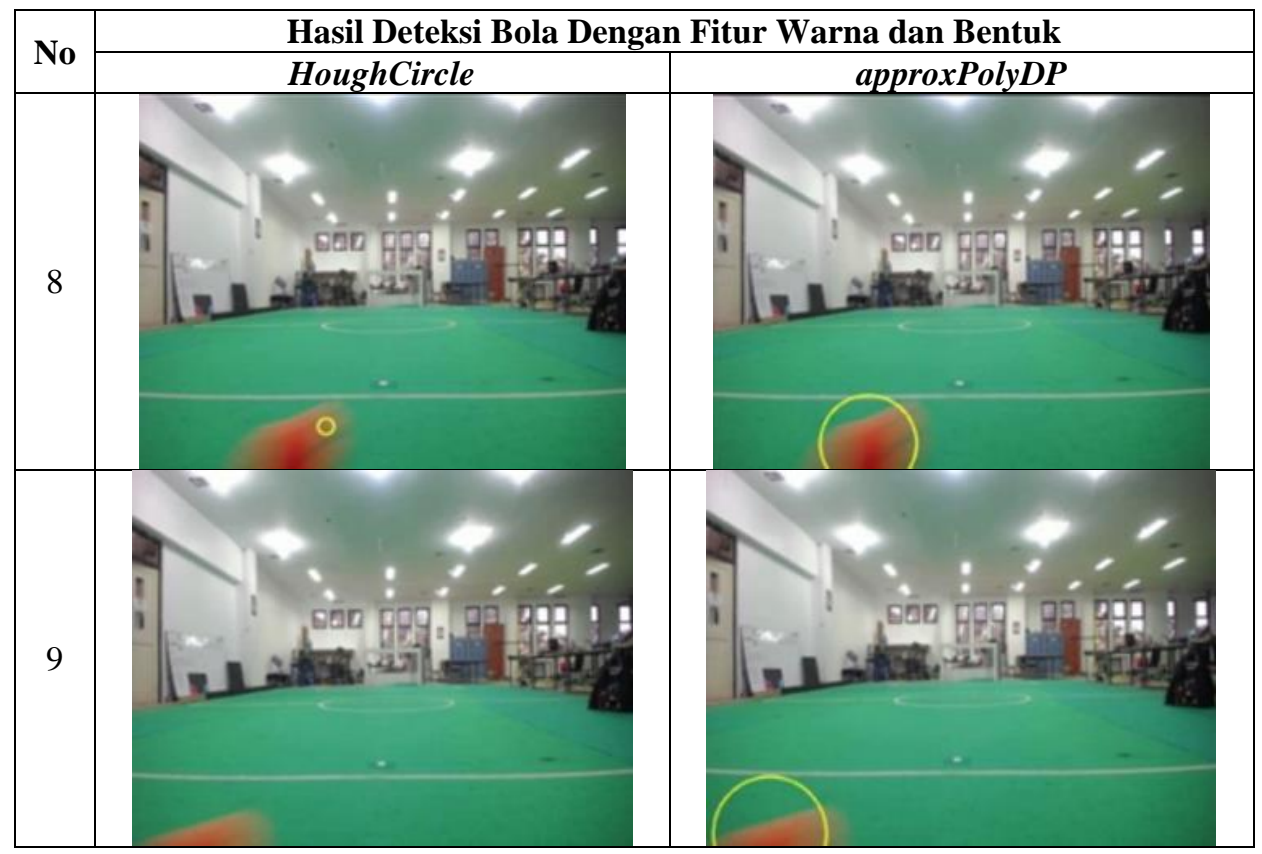

Dari data pengujian sistem deteksi bola yang ditunjukkan pada Tabel 1, kedua metode yang digunakan untuk deteksi bentuk dapat dikombinasikan dengan deteksi berdasarkan warna. Dari data pengujian tersebut juga dapat dilihat performa dari kedua metode deteksi bentuk yang digunakan. Deteksi bentuk menggunakan approxPolyDP memiliki tingkat kehandalan yang lebih tinggi, dibuktikan dengan masih dapat terdeteksinya bola walaupun bola bergerak sangat cepat dan bola pada frame terlihat seperti bayangan. Hanya saja, masih terdapat kemungkinan bola tidak dapat terdeteksi baik menggunakan metode HoughCircle dan approxPolyDP. Kemungkinan ini muncul jika bentuk bola pada citra tidak berbentuk minimal setengah lingkaran. Kondisi bola yang tidak berbentuk lingkaran ini bisa dikarenakan bola tertutup robot, citra bola ikut tereliminasi pada proses sebelumnya, atau bisa juga dikarenakan perubahan bentuk bola pada citra akibat bola bergerak.

Pengujian sistem deteksi ini kemudian dilakukan berulang-ulang menggunakan data masukan yang sama untuk melihat waktu proses yang dibutuhkan. Hasil pengujian ini ditampilkan pada Tabel 2. Dari Tabel 2, waktu rata-rata yang dibutuhkan untuk menjalankan proses deteksi berdasarkan warna dan bentuk menggunakan metode HoughCircle membutuhkan waktu 33,6 ms. Sedangkan waktu yang dibutuhkan untuk menjalankan proses deteksi berdasarkan warna dan bentuk menggunakan approxPolyDP membutuhkan waktu $17,8 \mathrm{~ms}$, atau lebih cepat sekitar $15,8 \mathrm{~ms}$.

Tabel 2. Waktu Proses

\begin{tabular}{|l|l|l|}
\hline Pengujian ke- & \multicolumn{2}{|c|}{$\begin{array}{c}\text { Waktu Deteksi Berdasarkan } \\
\text { Warna dan bentuk (ms) }\end{array}$} \\
\cline { 2 - 3 } & HoughCircle & approxPolyDP \\
\hline
\end{tabular}

\begin{tabular}{|c|r|r|}
\hline 1 & 33,0 & 19,0 \\
\hline 2 & 34,0 & 16,0 \\
\hline 3 & 28,0 & 18,0 \\
\hline 4 & 39,0 & 19,0 \\
\hline 5 & 34,0 & 17,0 \\
\hline $\begin{array}{l}\text { Rata - Rata } \\
\text { Waktu (ms) }\end{array}$ & $\mathbf{3 3 , 6}$ & $\mathbf{1 7 , 8}$ \\
\hline
\end{tabular}

\section{Kesimpulan}

Berdasarkan hasil penelitian dan pembahasan dapat diambil kesimpulan yaitu :

1. Proses eliminasi yang dibangun berhasil digunakan untuk memisahkan area dalam dan luar lapangan pada citra masukan.

2. Kombinasi antara deteksi warna dan bentuk akan semakin meminimalisir kesalahan sistem deteksi bola akibat adanya objek lain yang memiliki warna yang sama dengan warna bola.

3. Penggunaan metode approxPolyDP pada deteksi bentuk bola memiliki kehandalan yang lebih tinggi dibandingkan dengan menggunakan metode HoughCircle. Dari sisi waktu proses, deteksi bola yang menggunakan kombinasi deteksi warna dan deteksi bentuk menggunakan approxPolyDP juga lebih cepat sekitar 15,8 ms dibandingkan kombinasi antara deteksi warna dan deteksi bentuk menggunakan HoughCircle.

Penelitian ini masih jauh dari kata sempurna, dan masih terdapat beberapa bagian yang masih bisa dikembangkan diantaranya tingkat kehandalan dalam mendeteksi bola. Kedepannya, hasil dari penelitian ini akan dikombinasikan dengan sistem pengukur jarak serta sistem prediksi arah pergerakan bola. Dari kombinasi beberapa sistem ini nantinya dapat digunakan sebagai kemampuan tambahan pada robot 
kiper saat akan menghadang bola yang akan masuk kedalam gawang.

\section{Ucapan Terimakasih}

Ucapan terimakasih yang setinggi-tingginya kepada Kementerian Pendidikan dan Kebudayaan atas pembiayaan pendidikan dan riset melalui program Beasiswa Pendidikan Pascasarjana Dalam Negeri (BPPDN), serta rekan-rekan lab SVG Politeknik Elektronika Negeri Surabaya (PENS) dan rekan-rekan lab robotika Polibatam yang telah membantu selama riset ini dikerjakan.

\section{Daftar Pustaka}

[1] I. Udlhiya, B. Supriyo, and E. D. Wardihani, "Sistem Deteksi Sudut Gawang dengan Teknik Pengolahan Citra Digital berbasis Labview," pp. 419-425, 2019.

[2] M. I. Bustami, A. N. Toscany, and A. P. Prakarsa, "Perancangan Sistem Navigasi Menggunakan Metode Greedy Robot Sepakbola Beroda Dengan," vol. 16, no. 1, pp. 33-44, 2021.

[3] S. N. Rouf Alfan Rifai1, Nasrul Rofiah Hidayati2, "Program studi teknik informatika - universitas pgri madiun | 316," pp. 316$323,2018$.

[4] I. K. Wibowo, M. A. Haq, M. M. Bachtiar, B. S. B. Dewantara, and F. L. H. Ihsan, "Ball Detection using Local Binary Pattern in Middle Size Robot Soccer (ERSOW)," Proc. - 2019 2nd Int. Conf. Comput. Informatics Eng. Artif. Intell. Roles Ind. Revolut. 4.0, IC2IE 2019, pp. 29-32, Sep. 2019.

[5] A. W. Pradana and D. Irmawati, "Pendeteksi Warna dan Bentuk Bola Pada Robot Penjaga Gawang Menggunakan EmguCV," Elinvo (Electronics, Informatics, Vocat. Educ., vol. 5, no. $1,2020$.

[6] Winarno, A. S. Agoes, E. I. Agustin, and D. Arifianto, "Object detection for KRSBI robot soccer using PeleeNet on omnidirectional camera," Telkomnika (Telecommunication Comput. Electron. Control., vol. 18, no. 4, pp. 1942-1953, 2020.

[7] R. D. Listianto, S. Sunardi, and R. D. Puriyanto, "Monitoring Tegangan Baterai Lithium Polymer pada Robot Sepak Bola Beroda secara Nirkabel," Bul. Ilm. Sarj. Tek. Elektro, vol. 1, no. 1, p. 1, 2019.

[8] S. U. Ahmed, H. Ayaz, H. Khalid, A. Ahmed, M. Affan, and D. Muhammad, "Smart Goal Keeper Prototype using
Computer Vision and Raspberry Pi," 2020 10th Int. Conf. Adv. Comput. Inf. Technol. ACIT 2020 - Proc., pp. 867-870, 2020.

[9] M. B. SATRIYO, K. ANAM, and M. A. P. NEGARA, "Sistem Kontrol Robot Sepak Bola Beroda menggunakan Finite State Machine (FSM)," ELKOMIKA J. Tek. Energi Elektr. Tek. Telekomun. Tek. Elektron., vol. 9, no. 2, p. 344, 2021.

[10] S. R. Santosa, B. S. B. Dewantara, and I. K. Wibowo, "Ball Detection under Variety Lighting using Omnidirectional Camera," in IES 2019 - International Electronics Symposium: The Role of Techno-Intelligence in Creating an Open Energy System Towards Energy Democracy, Proceedings, 2019, pp. 235-240.

[11] B. S. B. Dewantara and B. N. D. Ariyadi, "Adaptive Behavior Control for Robot Soccer Navigation Using Fuzzy-based Social Force Model," Smart Sci., 2021.

[12] Y. Altun and U.-K. Y1lmaz, "Development of Algorithm Using Fuzzy Logic for Forward Players," J. Comput. Hardw. Eng., vol. 1, no. 2, pp. 1-8, 2018.

[13] Setiawardhana, Rudy Dikairono, Djoko Purwanto, and Tri Arief Sardjono, "Navigasi Robot Penjaga Gawang Berdasarkan Prediksi Posisi dan Waktu Kedatangan Bola," J. Nas. Tek. Elektro dan Teknol. Inf., vol. 9, no. 3, pp. 296-304, 2020.

[14] Y. Haryudanta D., F. D. Setiaji, and G. Dewantoro, "Rancang Bangun Mekanisme Penendang Bola Berbasis Elektromagnetik untuk Robot Sepakbola Beroda R2CWarrior," Techné J. Ilm. Elektrotek., vol. 17, no. 01, pp. 49-57, 2018.

[15] A. Engineering, "Development of ball direction prediction system for wheeled soccer robot goalkeeper using trigonometry technique and neural network method," no. October, pp. 24-25, 2019.

[16] M. R. Naufal et al., "Rancang Bangun Mekanik Ekspansi Robot Goalkeeper Sepak Bola Beroda Menggunakan Pneumatik," 6th Indones. Symp. Robot. Syst. Control, no. July, pp. 99-103, 2018.

[17] R. T. Yunardi, D. Arifianto, F. Bachtiar, and J. I. Prananingrum, "Holonomic Implementation of Three Wheels Omnidirectional Mobile Robot using DC Motors," J. Robot. Control, vol. 2, no. 2, 2021. 